We desire to thank Professor W. J. B. Riddeli for kindly placing the facilities of the Tennant Institute at our disposal, and also Mr. John Watt for his technical assistance.

\title{
REFERENCES
}

COATS, GEORGE.-Ophthalmoscope, Vol. VII, p. 724, 1909.

Bailey, Percival. - In Wilder Penfield's Cytology and Cellular Pathology of the Nervous system. Vol. III, p. 943. Hoeber, New York. 1932.

Davie.-Arch. of Ophthal., Vol. XXII, p. 760, 1939.

VAN DER HoEve.-Graefe Arch. Ophthal., Fuchs Festschrift, Vol. CV, p. 880, 1921.

Modern Trends in Ophthalmology, p. 124, London. 1940.

Heidelberger Berichte, Vol: LI, p. 136, 1936.

JULER, F. and MANN, I.-Trans. Ophthal. Soc. U.K., Vol. XLII, p. 87, 1922.

LoewensteIn and STEEL.-Amer. $J l$. Ophthal., Vol. XXIV, p. 731, 1941.

LOEWENSTEIN. -Brit. Jl. Ophthal., Vol. XXIX, p. 180, 1945.

MAN , I.-Development of the Human Eye. Cambridge. 1928.

RoBson, BlaCKWOOD and CoOKson.-Brit. Jl. Ophthal., Vol. XXV, p. 431, 1941.

STAllaRD.-Brit. Jl. Ophthal., Vol. XXII, p. 11, 1938.

\section{CONJUNCTIVAL HAEMORRHAGE DUE TO AN INFECTION OF NEWCASTLE VIRUS OF FOWLS IN MAN* \\ (Laboratory and Contact Infection)}

BY

\author{
N. I. SHIMKIN \\ HAIFA, PALESTINE
}

IN the ophthalmic literature, no case of haemorrhagic conjunctivitis due to the Newcastle virus of fowls, has been mentioned up to the present date as occurring in man.

As is known, this Newcastle virus disease causes a $90-100$ per cent. mortality in fowls. The disease got its name from the City of Nèwcastle-on-Tyne, England, where it first appeared in 1926, and was described in detail by Doyle in 1927. He proved that this epidemic was caused by a filter-passing virus which, as proved also by others, was fatal to fowls even in the dilution of $10^{6}$.

This disease of fowls is widely spread in the East, but has been observed in the West, viz., in England, only twice, in 1926 and 1933.

In Palestine, the disease first appeared in 1937, and was described by A. Komarov, D.V.M., Government of Palestine Poultry Diseases Officer, Northern District; it re-appeared in 1945.

A case of laboratory infection in man caused by Newcastle virus

- Received for publication, March 12, 1945. 
was observed by the author of this article in Haifa at the end of 1945 , and was demonstrated by him at the Meeting of the Haifa Ophthalmological Society on January 2, 1946.

\section{The case}

On December 11, 1945, Miss L. G., aged 23 years, an Assistant of Dr. A. Komarov, at the Government Laboratory, Poultry Diseases Offices, Northern District, Palestine, consulted me, and gave this history. On December 7, she was injecting poultry for protective vaccination with amniotic fluid from a chicken egg (dilution $1: 3,000)$. During the work she touched the upper eyelid of the left eye with her forefinger. On the following day the lid became reddish, and the redness increased still further. She applied 2 per cent. boracic lotion, and continued working. On December 11 , she came complaining of a slight soreness and a great redness of the left eye. She informed me that, on the same day, an orderly helping her had also touched his eye, but had washed the fluid off carefully. He was seen by the author on December 12 , but no signs of any reaction were observed.

On Examination:-The left upper eye-lid was slightly proptosed and the skin slightly oedematous. Along the whole length of the eyelid a dark blue strip of subcutaneous haemorrhage, 2-3 mm. broad, was observed; and, on raising the upper lid, a heavy subconjunctival haemorrhage covering the upper and outer part of the conjunctival sclera was seen. No discharge was observed. All pupillary reactions were normal, as well as all movements of the eyeball. Vision : right and left eye, 6/6. Fundus oculi normal. The patient was sent home with drops (zinc sulph. 0.02, cocaini muriatici $0 \cdot 10$, adrenalini hydrochlorici 10 guttae, aqua distillata' 10.0).

Differential Diagnosis :-In this case, it was natural to suspect a severe blow as the cause of the subcutaneous and subconjunctival haemorrhage, but this was not so. The age and the general health of the patient were proof of absence of subconjunctival haemorrhage due to a sclerosis of the vessels. The absence of discharge and any inflammatory symptoms, normal conjunctiva in places which were not covered with haemorrhage, and of any bacteriological findings, militated against diagnosing the case as an acute haemorrhagic conjunctivitis of Koch-Weeks origin. This disease occurs sporadically in Palestine in winter time, and causes epidemics in the hot and dry seasons (Shimkin).

The patient came for a second examination 3 days later. The subcutaneous and subconjunctival haemorrhage had begun to be absorbed. This process continued until January 2,1946 , when the patient was demonstrated to the Ophthalmological Society of Haifa. 
At the meeting, when the patient was seen by eye surgeons, a very narrow strip of haemorrhage still remained on the outer part of the limbus. The Secretary of the Society, Dr. Faig, mentioned that he had just seen, in his private practice, a similar case of subconjunctival haemorrhage, without any signs of inflammation, in a woman, and had not suspected that the cause might be attributed to the Newcastle virus. Dr. A. Komarov, D.V.M., M.Sc., suggested asking Dr. Faig's patient whether she had, a few days earlier, prepared for cooking a fowl bought in the market. This later proved to be the case.

\section{Review of Literature}

A large literature on the subject of the Newcastle virus of fowls, from the first outbreak in 1926 up to the beginning of 1943 , with 77 references, was collected and carefully studied by F. R. Beaudette, D.V.M.; it includes no mention of contagiousness for man.

The first case of human laboratory infection was published by F. M. Burnet, at the end of 1943 . No original of that article being on hand, the following extract from the Veterinary Bulletin of 1944 , number 14, pp. 300-301), kindly sent to the author of this article by Dr. Gur, V.M.D., Government of Palestine Poultry Diseases Offices, Southern District, is given below :-

"A case is reported of infection in a human being with the virus of Newcastle disease of fowls. The source of the infection was the accidental squirting of a large inoculum of highly infectious allantoic fluid from an experimentally infected egg. An acute conjunctivitis developed and persisted for one week, during which local treatment was applied. The virus was isolated from the discharge from the eye, and anti-body response was demonstrated by means of the Hirst technique."

As is shown in the Veterinary Medical literature (Beaudette) it is well known that the Newcastle virus acts by attacking the blood system of poultry. In post-mortems of diseased fowls, the changes in the vessels are very pronounced, particularly in those of the mucous and serous membranes, as well as in the subcutaneous tissues and muscles, and all inner organs. Thus the compact subconjunctival and subcutaneous haemorrhages of the eye-lid may be taken for acute conjunctivitis by medical men not experienced in eye diseases.

In Palestine a small epidemic of contact infection by Newcastle-virus occurred at the Agricultural School, Mikveh-Israel, where there was an outbreak of Newcastle epidemics of poultry; these cases were first reported by Dr. Yatom, Mikveh-Israel, in February, 1946.

"The cases, mostly women, kitchen personnel engaged in preparing poultry for the table, were confined to individuals who had 
come in contact with chickens from a chicken run infected with Newcastle disease. There were 17 cases, 3 men and 14 women, aged 13-70 years."' (Personal communication.)

The cause of this kitchen outbreak is that the Newcastle virus is contained in all the parts and tissues of the body of fowls; in secretions and excrements; in saliva, faeces, liver, spleen, lungs, pancreas, egg-yolk, testes, intestines,. bile, crop contents, and especially in the brain and cord, where the concentration of virus is very great; the virus is also present in the blood and pericardium. All this readily explains the infections of peopie who had touched diseased fowls, while preparing them for cooking. It is surprising that the number of patients was so few. Dr. Yatom considered that the clinical picture was reminiscent of the conjunctivitis epidemic in Palestine; but it was distinguished by its confinement to one eye only, and without the involvement of the cornea. This last fact may be easily explained in that the virus attacks blood-vessels, and these are absent from the cornea.

This outbreak stopped abruptly after the infected poultry had been destroyed. The incubatiom period in 3 male and 14 female cases lasted 3-4 days. All the symptoms disappeared after 10-14 days. There was no case of contact infection from man to man (from wife to husband or her children).

\section{Summary}

1. A case of conjunctival haemorrhage in man, due to Newcastle virus infection of fowls, is described.

2. This conjunctival haemorrhage in man can be caused by laboratory experiments, or by contact with infected poultry.

3 . The disease, up till now, was observed only in one eye of each patient; the incubation period is 3-4 days, and all the symptoms disappear in 7-14 days, without any later complications.

4. The action of Newcastle virus in fowls is to attack the walls of the blood vessels; the haemorrhage in man is due to the action of the virus on the conjunctival vessels.

5 . This condition may be called haemorrhagia subconjunctivalis and subcutanea of man, due to infection of Newcastle virus.

\section{REFERENCES}

1. Benudette, F. R.-A review of the literature of Newcastle virus diseases. New Jersey Agricultural Experiment Station, New Brunswick, New Jersey. Reprinted from Proceedings Forty Seventh Annual Meeting of the United States Livestock Sanitary Association, December 2, 3 and 4, 1943.

2. Doyle, T. M. (a) - A hitherto unrecorded disease of fowls, due to a filterpassing virus. Jl. Comp. Path. and Therap., Vol. XL, Part 2, pp. 144169, June, 1927. (b) Newcastle diseases in the virus of animals, with special reference to those of poultry. Jl. Comp. Path. and Therap., Vol. XLVI, Part 2, pp. 90-107, June, 1943. 
3. YATOM, J.-An outbreak of conjunctivitis in man, associated with the virus of Newcastle diseases. Harefuah, N.3, February 1, 1946.

4. Shimkin, N. I. $(a)$-The epidemiology of eye diseases in Palestine. Hebrew Harefuah A. Med. Jl., Vol. I, No. 4-5, April, 1945. (b) La Maladie des yeux Haifa, Palestine. Ann. d'Ocul., December, 1924. (c) Blindness among Jews in Palestine, and its causes. Congress International, Cairo, Egypt, 1928.

\title{
HISTORY OF OPHTHALMOLOGY THROUGH THE AGES* $\dagger$
}

\author{
BY
}

\section{J. R. WHEELER}

BELFAST

TODAY, as the result of war, we are living in one of those crises of history which cause a great social upheaval in human society. Steady peaceful progress is replaced by a sudden jerk forward and, as a result, we must adapt ourselves to the new environment.

The future position of our profession in its relationship to the State is being examined by our legislative authorities, and so it behoves us (the present holders of our birthright) to be certain that the public, and we ourselves, have our views clearly set out.

That great statesman, Winston Churchill, recently remarked, " The longer you can look back the further you can look forward." And so to-day I propose to trace the history of ophthalmology from the earliest times, race you through the middle ages and so up to the present day. I will endeavour to pick out the chief actors and emphasise the part they played in unravelling the history of about 4,200 years.

The uncertainties of unrecorded history make it impossible to say. where the dawn of civilisation began, but the earliest mention of any medical matter is found in an ancient work on law. About 2250 B.C. Hammurabi-a king of Babylon-Assyria-promulgated a collection of laws. A considerable number of sections of these laws relate to ophthalmology-or rather to ophthalmic negligence or malpractice-e.g., one such law states that:-

(196). If a man destroy the eye of another man, they shall destroy his eye. (In the case of a freeman he shall pay one manna of silver and, in the case of a slave he shall pay one half his price.)

Another states :-

(215). If a physician open an abscess in a man's eye with a

* Received for publication, October 6, 1945.

+Address at the opening of the Winter Session at the Royal Victoria Hospital, Belfast, on October 10, 1945. 